\title{
HARDENING OF LEADING EDGES OF TURBINE BLADES BY ELECTROSPARK ALLOYING
}

\author{
${ }^{1}$ N.E. Kalinina, ${ }^{2}$ D.B. Hlushkova, ${ }^{2}$ O.D. Hrinchenko, ${ }^{3}$ V.T. Kalinin, \\ ${ }^{2}$ A.I. Voronkov, ${ }^{2}$ L.L. Kostina, ${ }^{2}$ I.N. Nikitchenko, ${ }^{1}$ T.V. Nosova, ${ }^{2}$ A.A. Reznikov \\ ${ }^{1}$ Oles Honchar Dnipro National University, \\ Dnipro, Ukraine \\ E-mail: kalinina.dnu@gmail.com; \\ ${ }^{2}$ Kharkiv National Automobile and Highway University, \\ Kharkiv, Ukraine \\ E-mail: diana@khadi.kharkiv.ua; \\ ${ }^{3}$ National Metallurgical Academy of Ukraine, \\ Dnipro, Ukraine \\ E-mail: vt.kalinin@gmail.com
}

With a purpose of creating anti-erosion protection on turbine rotor blades the experiments in electrospark alloying using electrodes made of different materials: T15K6 hard alloy and 15X11MФШ steel were conducted. Reduction of the roughness of a surface layer having a uniform thickness was achieved upon its hardening with a steel electrode. The electrospark alloying process was perfected. Tests of mechanical properties of blade samples hardened with steel revealed overmatch of GOST requirements for strength and ductility. Increasing of surface layer microhardness was also achieved. For anti-erosion protection of leading edges of the turbine rotor blades it is recommended to replace the applied electrode made ofT15 К6 alloy with the one made of 15X11MФШ steel.

\section{INTRODUCTION}

While in operation rotor blades of turbine wet-steam stages are affected by various destructive factors: a corrosive environment, repeated alternations. As a result, turbine blades suffer erosion-corrosion wear. In addition, presence of a liquid phase in the working medium of steam turbines causes additional energy losses in turbine stages and erosive wear of the flow range elements due to deterioration of profile aerodynamic characteristics and loss in reliability in dices of the blade system [1].

One of the most important issues is development of new, non-tradition al for the power-plant industry, effective methods to protect leading edges of aft stages blades in steam turbines rotors against erosioncorrosion wear caused by humidity in the working medium of turbines. It is known [2] that the most effective way to improve erosion resistance of structural materials is application of protective wear-resistant coatings and hardening of the part surfaces.

Erosion protection of the flow range (leading edges of rotor blades) is mainly implemented with the help of hardening the areas being exposed to humidity most of all.

Traditional methods for protecting rotor blades of steam turbines operating in the phase transition zone are high-frequency current hardening of leading edges and their electrospark alloying with hard alloy. Highfrequency current hardenings how positive results for improving erosion resistance, but a lack of possibility to harden the area of the radius transition to a desk-type bandage is a disadvantage of this method [3, 4]. Taking into account topicality of finding new methods for protecting leading edges of rotor blades at the low- pressure aft stages, a research was carried out to explore a possibility of hardening the leading edges of rotor blades with 15X11MФШ commercial steel, applying the electrospark alloying method (ESA).

The results of experiments for hardening the leading edges of rotor blades with $15 \mathrm{X} 11 \mathrm{MФШ} \mathrm{steel} \mathrm{vs.}$ hardening the blades withT15K6 hard alloy are given in this research paper.

T15K6 titanium-tungsten carbide alloy for hardening the rotor blades is limited in its application in atomic power plants due to presence of cobalt in the alloy composition as an element producing long-lived isotopes as a result of its activation $[2,5]$

\section{SUBJECT AND METHODS OF RESEARCH}

15X11MФШ steel used for Production of turbine rotor blades was testedasan electrode for electrospark alloying. Properties of surface layers hardened with T15K16 sintered alloy and 15X11МФШ steel were compared.

The method of electrospark alloy in gisbased on the phenomenon of electrical erosion of materials during as park discharge in a gaseous medium, polar transit of erosion products onto a layer of altered structure and an alloy [3,4]. Asa result of electrical break down of the inter electrodes pacing a spark discharge emerges, in which the electron stream leads to a local heating of the electrode (anode) [3,4-6]. There is mixing of cathode and anode material occurring on the cathode surface under the influence of significant thermal loads, which promotes formation of a high adhesion between the substrate and the generated layer [5, 6]. Fig. 2 shows a general scheme of electrospark alloying process (ESA). 


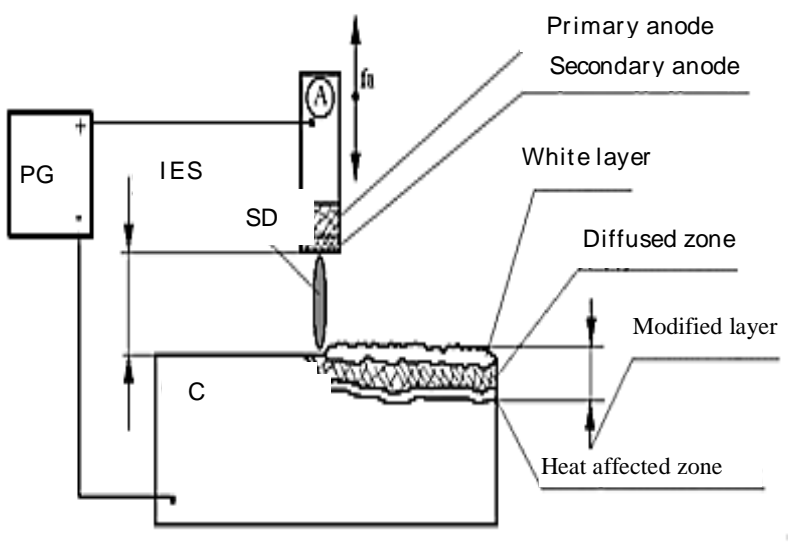

Fig. 1. General scheme of ESA process with the vibrating anode: $P G$ - pulse generator; IES - inter electrodes pacing; $S D$ - spark discharge; $A$ - anode (compact electrode); $C$-cathode, frequency of anode vibration

The composition of the alloyed layer can differ fundamentally from the composition of the blades basic materials. It is caused by the specific nature of ESA effect that consists in an ultra-high speed of temperature rise and cooling, a contact between surfaces and with elements of the environment in conditions of impulse influence of high temperatures and pressures [4-6].

\section{RESEARCH RESULTS AND DISCUSSION}

The works on hardening the blades samples were executed on the electrical discharge machine of ЭИЛ8 Amodel $[5,6]$ in the mode: pulse current amplitude value $\mathrm{I}=(175 \pm 10) \mathrm{A}$, pulse energy $\mathrm{E}_{\text {pulse }}=3.15 \mathrm{~J}$, pulse duration time $t_{\text {pulse }}=1000 \mathrm{~ms}$, frequency at $600 \mathrm{~Hz}$.

The research was carried out on the samples cut from rotor blade blank parts of 15X11МФШ steel manufactured by the forged method and heat-treated up to hardness of $271 \mathrm{HB}$. Chemical properties of the samples tested are given in Tabl. 1, whereas their mechanical properties are set out in Tabl. 2 .

Elemental composition of 15X11MФШ steel test samples

Table 1

\begin{tabular}{|c|c|c|c|c|c|c|c|c|c|}
\hline \multirow{2}{*}{ Type of steel } & \multicolumn{7}{|c|}{ Content of chemical elements, \% } \\
\cline { 2 - 10 } & $\mathrm{C}$ & $\mathrm{Cr}$ & $\mathrm{Ni}$ & $\mathrm{Mo}$ & $\mathrm{V}$ & $\mathrm{Si}$ & $\mathrm{Mn}$ & $\mathrm{S}$ & $\mathrm{P}$ \\
\hline $\begin{array}{c}\text { Actual } \\
\text { composition }\end{array}$ & 0.14 & 10.5 & 0.26 & 0.63 & 0.3 & 0.18 & 0.33 & 0.013 & 0.022 \\
\hline $\begin{array}{c}\text { Requirements of } \\
\text { ГOCT5632-72 }\end{array}$ & $0.12 \ldots 0.19$ & $10.0 \ldots 11.5$ & - & $0.6 \ldots 0.8$ & $0.25 \ldots 0.4$ & $\leq 0.5$ & $\leq 0.7$ & $\leq 0.025$ & $\leq 0.03$ \\
\hline
\end{tabular}

Table 2

Mechanical properties of 15X11МФШ steel test samples

\begin{tabular}{|c|c|c|c|c|c|c|}
\hline Mechanical properties & $\sigma_{0.2}, \mathrm{MPa}$ & $\sigma_{\mathrm{B}}, \mathrm{MPa}$ & $\delta_{5}, \%$ & $\Psi, \%$ & $\mathrm{KCU}, \mathrm{J} / \mathrm{cm}^{2}$ & $\mathrm{HB}$ \\
\hline Test results & 6690 & 8270 & 20 & 58 & 116 & 271 \\
\hline $\begin{array}{c}\text { Requirements of } \\
\text { OCT 108.020.03-82 }\end{array}$ & $6664 \ldots 8134$ & $\geq 8140$ & $\geq 13$ & $\geq 40$ & $\geq 39.2$ & $248 \ldots 285$ \\
\hline
\end{tabular}

Microstructure of the samples parent metal upon the hardening heat-treatment constitutes a sorbitol with preservation of martensitic planes orientation. Structure of the samples is notable for its uniformity, grains of different etch ability can be observed within the structure, the size of martensitic needles corresponds to 7-8 points of GOST 8233-96 (Fig. 2).

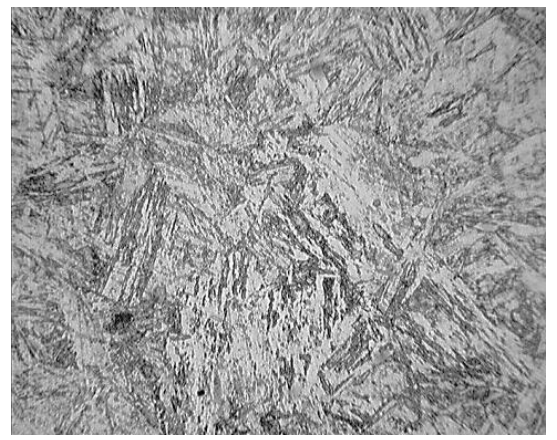

Fig. 2. Microstructure of the blade metal upon the bulk heat treatment, $\times 100$

A study of roughness of the hardened layers surface revealed heterogeneity, hardening is performed unevenly due to the hardening pulse discreteness. The surface roughness of the samples hardened withT15K6 alloy was 2.8 times coarser than that of the sample hardened with $15 X 11 \mathrm{MФШ} \mathrm{steel} \mathrm{(43.9} \mathrm{and} 15.3 \mu \mathrm{m}$ respectively). There were no critical defects of cracks type detected on the surface of the samples.

With a purpose of evaluating the quality of bond between the alloyed layers and the parent material the samples hardened were tested according the following scheme:

- a bend test with the bend angle of $90^{\circ}$ with the bend former used $R=40 \mathrm{~mm}$;

- a bend test with the bend angle of $180^{\circ}$ with the bend former used $R=20 \mathrm{~mm}$.

There was no destruction in all the samples tested. There were breaks in the sections bent at the angles of 90 and $180^{\circ}$, but no peeling of the layers hardened withT15К6 and 15X11МФШ was detected.

The hardened surface layer features heterogeneity through thickness of the layer, but the average thickness values in case of hardening with T15K6 alloy and hardening with $15 \mathrm{X} 11 \mathrm{M} Ф \amalg$ steel practically coincide and amount to $0.075 \ldots 0.080$. 
Fig. 3 shows histograms of micro hardness measurements of the test samples surface layers.
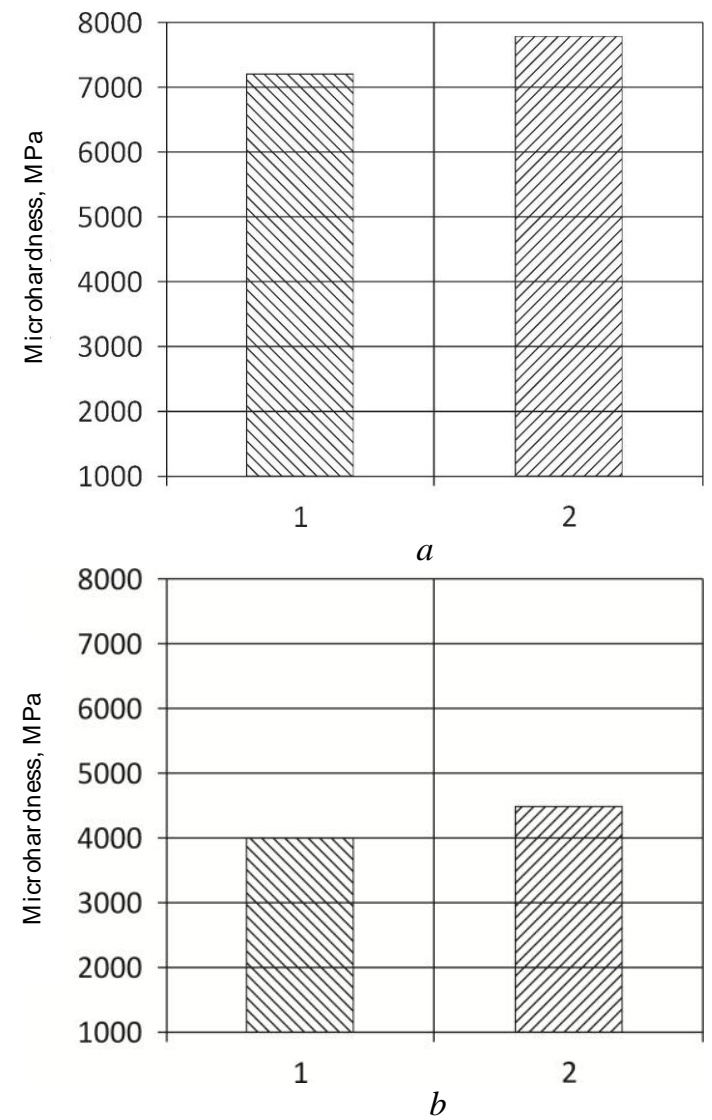

Fig. 3. Histograms of microhardness HV of the test samples hardened with T15K6 alloy (1) and 15X11MФШ steel (2): a-hardened layer; $b$-transition (diffusion) zone

Microhardness on the hardened layer surface was higher when using $15 \mathrm{X} 11 \mathrm{MФШ} \mathrm{steel}(8000 \mathrm{MPa})$ than when using T15K6 hard alloy (7500 MPa). Micro hardness of the transition zone and the heat-affected zone at different distances from the "parent metalhardened layer" border was also higher when hardening was performed with a steel electrode.

The metallographic investigation revealed that the hardened surface layer on the both samples had a clear dendritic structure. It was detected with the help of $\mathrm{X}$-ray diffraction method that the layer hardened with T15K6 consisted of ferrite to a large extent, austenite, titanium-tungsten carbides as well as pure cobalt. In the layers hardened with steel there was ferrite, austenite and chromium-molybdenum carbide ensuring the strengthening effect.

\section{CONCLUSIONS}

1. For erosion-resistant protection of turbine rotor blades it is suggested to use material of $15 \mathrm{X} 11 \mathrm{MФШ}$ electrode being identical to the steel used for production of steam turbine rotor blades that enables to cut down electrode material consumption for electrospark alloying.

2. It is established that roughness of the layer made with $15 \mathrm{X} 11 \mathrm{MФШ} \mathrm{steel} \mathrm{is} \mathrm{lower} \mathrm{than} \mathrm{when} \mathrm{using}$ T15K6 hard alloy.
3. The average thickness values of blade surface layers made in the same alloying modes with T15K6 alloy and 15X11MФШ steel practically coincide: $0.03 \ldots 0.06 \mathrm{~mm}$.

4. Microhardness of the surface layer hardened with 15Х11MФ-Ш steel is higher than when T15K6 hard alloy is used. Microhardness of the transition zone and the heat-affected zone at different distances from the "parent metal-hardened layer" border is practically the same.

5. Based on the research conducted it is possible to recommend replacing the applied strengthening electrode made of T15K6 hard alloy to 15X11МФШ steel for protection against the water droplet erosion of leading edges of turbine rotor blades.

\section{REFERENCES}

1. B. Luiset, F. Sanchette, A. Billard, D. Schuster. Mechanisms of stainless steels erosion by water droplets // Wear. 2013, v. 303, p. 459-464.

2. G.M.L. Murari, P. Singh. Turbine Blade Construction, Materials and Manufacture in de Blade Design and Analysis for Steam Turbines, McGraw Hill, 2011, p. 67-78.

3. Bernd M. Schonbauer, Stefanie E. StanzlTschegg, Andrea Perlega, Ronald N. Salzman, Neville F. Rieger, Shengqi Zhou, Alan Turnbull, David Gandy. Fatigue life estimation of pitted $12 \% \mathrm{Cr}$ steam turbine blade steel in different environments and at different stress ratios // International Journal of Fatigue. 2014; v. 65 , p. $33-43$.

4. Krunal K. Ratthod, Praful G. Patil, Purvik R. Patel. Heat Treatment of Steam-Turbine Rotor Blade by Induction Hardening // International Journal of Scientific \& Engineering Research. v. 8, issue 3, March-2017 694 ISSN 2229-5518 IJSER (C) 2017 http://www.ijser.org.

5. Technical Guides "PTM 108.020.15-86". Metals for turbines and heat-exchange equipment of nuclear power plants.

6. V.I. Kovalenko, L.I. Martynenko, V.G. Marinin. Study of erosion resistance of steels surface layers under cavitation // Eastern European Advanced Technology magazine. 2015, v. 2/5, p. 74

7. Bernd M. Schönbauer, Stefanie E. StanzlTschegg, Andrea Perlega, Ronald N. Salzman, Neville F. Rieger, Shengqi Zhou, Alan Turnbull, David Source Gandy. Fatigue life estimation of pitted $12 \% \mathrm{Cr}$ steam turbine blade steel in different environments and at different stress ratios // Fatigue of Metallic Materials Mechanisms and Life Estimation, International Journal of Fatigue. August 2014, v. 65, p. 33-43

8. H. Nomoto. High-performance technology of steam turbine blades // Toshiba review. 2010, v. 65, N 12, p. 66-67 (in Japanese).

9. Loveleen Kumar Bhagi, Pardeep Gupta, Vikas Rastogi. Fractographic investigations of the failure of L-1 low pressure steam turbine blade // Case Studies in Engineering Failure Analysis. 2013, v. 1, p. 72-78.

10. V.V. Sarantseva, A.V. Belyakov, Ph.I. Panteleenko, E.L. Azarenko. Equipment for and technology of electro spark alloying for service life extension of 
power equipment // Electronic treatment of materials. 2014, v. 50(5), p. 95-99.

11. V.L. Shvetsov, A.E. Kovalsky, G.N. Kartmazov, V.G. Solodov, I.I. Kozheshkurt, V.A. Konev. Combined anti-erosion protection of aft stage buckets of high-power turbines. Power and thermal engineering processes and equipment // Bulletin of the NTU “KhPI”. 2014, N 13, p. 1056.
12. G. Ilieva. Mechanisms of Water Droplets Deposition on Turbine Blade Surfaces and Erosion Wear Effects // Journal of Applied Fluid Mechanics. 2017, v. 10, N 2, p. 551-567,

13. Sandeep Soni. Analysis of liquid droplet erosion for steam turbine blades of composite material // Int. J. Mech. Eng. \& Rob. Res., 2012.

Article received 12.02.2019

\title{
УПРОЧНЕНИЕ ВХОДНЫХ КРОМОК ЛОПАТОК ТУРБИН ЭЛЕКТРОИСКРОВЫМ ЛЕГИРОВАНИЕМ
}

\author{
Н.Е. Калинина, Д.Б. Глуикова, Е.Д. Гринченко, В.Т. Калинин, \\ А.И. Воронков, Л.Л. Костина, И.Н. Никитченко, Т.В.Носова, А.А. Резников
}

\begin{abstract}
Для формирования противно эрозионной защиты рабочих лопаток турбины проведены эксперименты по электроискровому легированию электродами из различных материалов: твердого сплава Т15К6 и стали 15Х11МФШ. Достигнуто уменьшение шероховатости поверхностного слоя при одинаковой его толщине после упрочнения стальным электродом. Отработан режим электроискрового легирования. Испытания механических свойств образцов лопаток, упрочненных сталью, показали превышение требований ГОСТ по прочности и пластичности. Достигнуто также повышение микротвердости поверхностного слоя. Рекомендована замена применяемого электрода из сплава Т15 К6 на электрод из стали 15Х11МФШ для защиты от эрозии входных кромок рабочих лопаток турбин.
\end{abstract}

\section{ЗМІЦНЕННЯ ВХІДНИХ КРОМОК ЛОПАТОК ТУРБІН ЕЛЕКТРОІСКРОВИМ ЛЕГУВАННЯМ}

\section{Н.Є. Калініна, Д.Б. Глушкова, О.Д. Грінченко, В.Т. Калінін, А.І. Воронков, Л.Л. Костіна, І.Н. Нікітченко, Т.В. Носова, О.О. Резніков}

Для формування протиерозійного захисту робочих лопаток турбіни проведені експерименти 3 електроіскрового легування електродами з різних матеріалів: твердого сплаву Т15К6 і сталі 15Х11МФШ. Досягнуто зменшення шорсткості поверхневого шару, отриманого легуванням сталевим электродом, при однаковій товщині поверхневого шару. Відпрацьовано режим електроіскрового легування. Випробування механічних властивостей зразків лопаток, зміцнених сталлю, показали перевищення вимог ДСТУ 3 характеристик міцності та пластичності. Досягнуто також підвищення мікротвердості поверхневого шару. Рекомендована заміна електрода із сплаву Т15К6, що використовується, на електрод із сталі $15 \mathrm{X} 11 \mathrm{MФШ,}$ для захисту від ерозії вхідних кромок робочих лопаток турбін. 